\title{
Contemporary Scenario of Maxillofacial Trauma \& its management in Western Rajasthan
}

\author{
Dr Dinesh Pilania *, Dr Vikas Dev ${ }^{* *}$, Dr Chandrashekhar Chattopadhyay ${ }^{* * *}$ \\ ${ }^{*}$ MDS, Oral \& Maxillofacial Surgery, Senior Resident, Dept of Dentistry, Dr S N Medical College, Jodhpur, Rajasthan. \\ ${ }^{* * *}$ MDS, Periodontology, Professor \& Head, Dept of Dentistry, Dr S N Medical College, Jodhpur, Rajasthan. \\ **** MDS, Oral \& Maxillofacial Surgery, Associate Professor, Dept of Dentistry, Dr S N Medical College, Jodhpur, Rajasthan
}

DOI: 10.29322/IJSRP.11.12.2021.p12009

http://dx.doi.org/10.29322/IJSRP.11.12.2021.p12009

\begin{abstract}
Purpose: Maxillofacial trauma is identified as a major public health problem worldwide. The incidence and epidemiological causes of maxillofacial (MF) trauma varies regionally. This study presents contemporary state of maxillofacial trauma and its management, along with emerging trends and trauma patterns with changing era from slow moving vehicles to present-day high-speed transport modalities in Western part of Rajasthan comprising of 6 major districts.

Materials and Methods: - Data collected included demographic and injury details, and operative procedures done, it also outlines how despite recent advancements classic methods can still be use in high volume trauma centre with minimal available resources

Results: 554 patients were included in this study consisting of $93.7 \%$ male and $06.3 \%$ female, and the male-to-female ratio was $4.8: 1$. Mean age was $40.3 \pm 17.2$ years with a range of 18 to 97. $77.4 \%$ of the patients were between the ages of $18-39$ years and predominantly male. Above 60 years of age, referrals were mostly woman. The most common cause of injuries was road traffic accidents $80 \%$ violence $15 \%$, followed by falls.

The primary cause of injuries was RTA between ages 20 and 49 and falls after 60. Earlier most common fractures were reported of zygomaticomaxillary complex which gradually increased to Complex Pan facial trauma. Cases of Assault related injuries are also on rise, along with fall in senior citizens. $9 \%$ of the patients had brain injury and only frontal fractures are significantly associated. Male gender has statistically stronger association for suffering. Data revealed correlation with alcohol consumption and presence of fractures, though no definite conclusion can be drawn based on single study.
\end{abstract}

Conclusion: The need for prevention is must and has been highlighted as high-speed transport-related injuries remain high especially in the younger age groups. Younger surgeons should be well versed in recent advances as well as classic modalities of management especially when resources are Scares.

Index Terms- Maxillofacial, trauma, injuries, epidemiology.

\section{INTRODUCTION}

$\mathrm{R}$ apid transportation $\&$ industrialization will herald an increase in maxillofacial trauma".[1] An injury is any destructive change caused due to unexpected physical force resulting in transient or permanent loss of vitality [1].Trauma in Maxillo-facial region have a huge impact on the psychology and physical appearance of the patient and this impact remains persistent[2] . These injuries occupy a spectrum of complexity i.e. Minor dentoalveolar injuries proceeding to multisystem, life threatening injuries requiring multidisciplinary treatment \& complex reconstructive procedures\& may be life-threatening as a result of airway obstruction /haemorrhage. Functional complications such as injury to vital sensory structures responsible for vision, olfaction, hearing and taste causes' major depletion of patient's daily life routine and in major cases may even lead to mortality. It is a $5^{\text {th }}$ largest killer after Major killers as Cancers .Use of mobile phones while driving a vehicle is one of the major causes behind road side accidents. In spite of rapid urbanization and fast telecommunication, rules and regulations are not been followed by the general population on mandatory basis. Even though we see large number of road side accidents on frequent basis, yet the appropriate/reliable data is still lacking in terms of both reliability\& quality at both national and regional level $[4,5]$. These statistics can help in Prevention, and acute \& long-term care, \& rehabilitation.

The main causes of maxillofacial trauma in India varies from region to region. [4,5] Maxillofacial trauma involves fracture of mandible, adjacent soft tissues and mid-facial region. The ferocity and pattern of the injuries depends upon the area involved in traumatic injury, intensity and direction of the force. Uniqueness of maxillofacial skeleton region is being able to be divided into separate modules for classification and treatment planning. [6,7] Fracture patterns are been subdivided into

Table 1. Fracture Patterns [6,7]

\begin{tabular}{|c|c|c|}
\hline 1 & Nasal & $\begin{array}{ll}\text { - } & \text { Lateral Blow } \\
\text { - } & \text { Other } \\
\end{array}$ \\
\hline 2 & $\begin{array}{l}\text { Zygomaticomaxillary } \\
\text { complex }\end{array}$ & $\begin{array}{ll}\text { - } & \text { Zygomaticomaxillary } \\
& \text { complex } \\
\text { - } & \text { Arch only } \\
\text { - } & \text { Body of zygoma }\end{array}$ \\
\hline 3 & Maxilla & $\begin{array}{ll}\text { - } & \text { LeFort I } \\
\text { - } & \text { LeFort II } \\
\text { - } & \text { LeFort III }\end{array}$ \\
\hline
\end{tabular}




\begin{tabular}{|c|c|c|}
\hline 4 & Orbital & $\begin{array}{ll}\text { - } & \text { Blowout } \\
\text { - } & \text { Blowin }\end{array}$ \\
\hline 5 & $\begin{array}{l}\text { Frontal Sinus \& } \\
\text { Nasoorbitoethmoid }\end{array}$ & \\
\hline 6 & Mandibular & $\begin{array}{l}\text { - } \text { Parasymphysis } \\
\text { - Body } \\
\text { - Angle } \\
\text { - Ramus } \\
\text { - Subcondyle } \\
\end{array}$ \\
\hline 7 & Panfacial & $\begin{array}{l}\text { Various combination of all } \\
\text { 3rd's facial region fractures }\end{array}$ \\
\hline
\end{tabular}

\section{PICTURE 1.}

Comparative analysis of the current era shows us that the scenario of medical and paramedical services provides a drastic change in over-all rate of life expectancy of the general population due to recent advancements in the field of anaesthesia, intensive care and surgical procedures. Yet still, even more precision in Functional aesthetic rehabilitation of the patient is our prime goal, has to be achieved. Complications associated with maxillofacial trauma make it the $5^{\text {th }}$ largest killer worldwide but things are changing from last 2 decades. Advancements in maxillofacial imaging modalities and multiple surgical procedures like open craniofacial exposure, rigid internal fixation with immediate bone grafting shows a high bounce in the prognosis of traumatic injury. $[6,7,8]$

Our medical teaching institute has been enlisted as one of the biggest tertiary care teaching institute and hospital in the region of western Rajasthan catering to the 6 Major Districts with 754 bed capacity and 4 ICU units. Comprehensive data has been collected retrospectively and has been analysed from hospital. The aim of this study was to understand the cause and pattern of trauma and its management of west Rajasthan. All maxillofacial trauma cases a Multipronged approach in management is followed. A total of 554 patients were included in this study.

\section{PICTURE 2 ULTIMATE GOAL.}

\section{MAterials \& MethodS} analytic

Study Design: Retrospective, Descriptive Quantitative

Current study included all surviving patients reporting/referred for management of maxillofacial trauma to Department of General dentistry during a period of 6 years starting from April 2013 to August 2019. Patients were either referred from 6 surrounding district hospitals or other affiliated hospitals in the city. A few reported directly to Dental OPD. Department registration register was reviewed for Data collection, which included Biographic, demographic and injury details, and operative procedures carried out. However no religious details were reviewed. It was then distributed on the basis of Age, Gender, Urban vs Rural, type of Vehicles, \& Substance Abuse. It also outlines how despite recent advancements classic methods can still be use in high volume trauma center with minimal recourses.
A total of 554 patients were included in the study. Patients were also analyzed based on their area of residence and socioeconomic status. Descriptive analysis was done and results tabulated.

All patients were managed by Open reduction and Internal fixation either using General or Local Anaesthesia. Post-operative Intermaxillary fixation were done only in cases with minor occlusal discrepancy Many patients were treated as day care patients such as fracture Zygomatic complex, Fracture mandible with only angle or parasymphysis and body. Titanium Mini $(2.00 \mathrm{~mm})$ Plates, Titanium Microplates $(1.5 \mathrm{~mm}), \&$ in Some cases depending on reconstruction plates $(2.5 \mathrm{~mm})$ with corresponding screws were used. Intermaxillary fixation was done using IMF Screws or Screw retained Arch bars for speed.

Patients who refused treatment $\&$ those who Succumbed to death due to early or delayed complication were excluded.

\section{RESULT}

554 patients were included in the study, 93.7\% male and $06.3 \%$ females with a male to female ratio of $4.8: 1$. Mean age was $40.3+17.2$ yrs. Patients were also analysed based on their area of residence and socio-economic status. Collected data has been tabulated analysed for age, gender, mode of transportation and pattern of injury. [Chart 1, 2, 3]

The most common cause of injuries was road traffic accident that was found in about $80 \%$ of cases. Case of assault related injuries are also on a raise; it was followed by interpersonal violence by $15 \%$ in male individuals. Domestic violence has been a major reason behind trauma for female subjects followed by RTA and falls respectively. Cases with a wide age range were seen in between a range of 3 month to 97 yrs..9\% of the patients had brain injury and only frontal fractures are significantly associated. All the data were analysed statistically and shows that male gender has statistically stronger association for suffering $(p<0.05)$. Soft tissue area was involved in approximately $97 \%$ cases, followed by nasal bone, zygomatic complex, Mandible, Mid facial, pan-facial and sum total Craniomaxillofacial injuries. Especially a high incidence was noticed of alcohol abuse and intoxication [9].

All of these data are sum total analysed and narrated in tabular form as follows. [Chart 1, 2, 3]

\section{Discussion-}

Trauma, the leading cause of death in the first $2^{\text {nd }}$ to $4^{\text {th }}$ decade of life, is a major failure of wellbeing in physical emotional and social conduct. Maxillofacial traumas are been distributed by means of cause behind trauma into road traffic accident, interpersonal violence or rivalry, sport, and fall. This cause differs from country to country, area to are, locality to locality based on the regional, educational, social, cultural, environmental and moral factors $[13,14]$. A total of 554 patients were included in the study consisting of $93.7 \%$ male and $06.3 \%$ females with a male to female ratio of 4.8:1. Mean age was 40.3+_17.2 yrs. This is in conformity with other studies $[13,14]$

Distribution of gender for maxillofacial trauma shows high incidence in males and that is coinciding with other studies conducted elsewhere $[1,7,15,16,18,19] \cdot$ Male to female ratio was 
4.8:1 which corresponds with previous studies (4.2:1)[20]and Zimbabwe (5:1)[21].This might be due to the cause that Male gender is worldwide acclaimed to involve into movements ,physical fights, aggression and more of verbal abuse resulting into conflicts and trauma as compared to females. The most common cause of injuries was road traffic accident that was found in about $80 \%$ of cases. It is been followed by interpersonal violence by $15 \%$ in male individuals. Domestic violence has been a major reason behind trauma for female subjects followed by RTA and falls respectively. This is in concurrence to studies carried out in other developing countries [2021]. Cases of assault related injuries are also on a raise $9 \%$ of the patients had brain injury and only frontal fractures are significantly associated. Soft tissue area was involved in around $97 \%$ cases followed by Nasal, zygomatic complex, Mandible Mid facial, pan-facial and Craniofacial maxillofacial injuries. Especially a high incidence was noticed of alcohol abuse and intoxication. [9]

Two-wheeler riders were more frequently involved in comparison to 4-wheeler though severity of injuries could not objectively scored. This data is also similar to studies carried out in Nepal, Iran and Zimbabwe [15,16,21].

The incidence of ZMC fracture is highest followed by fracture mandible though over years incidence of pan facial fractures are showing a upward trend in our study. Alost all cases were managed by Open reduction and internal fixation using Titanium implants of various sizes and type depending on the site of fracture. Champys Osteosynthesis lines and facial horizontal and vertical buttress as guides to restore face.

\section{Declaration}

Funding: NO Funding received.

Conflict of interest: Author1 declares that he has no conflict of interest.

Author 2 declares that he has no conflict of

interest.

interest.

Author 3 declares that he has no conflict of

\section{"'Compliance with Ethical Standards"'"}

Ethical approval:

"All procedures performed in studies involving human participants were in accordance with the ethical standards of the institutional and/or national research committee and with the 1964 Helsinki declaration and its later amendments or comparable ethical standards." This article does not contain any studies with animals performed by any of the authors."

Informed consent: "Informed consent was obtained from all individual participants included in the study."

\section{REFERENCES}

[1] Holder Y, Peden M, Krug E, et al., editors. Injury surveillance guidelines. Geneva: World Health Organization; 2001.

[2] De Sousa A. Psychological issues in acquired facial trauma. Indian J Plast Surg. 2010;43(2):200.

[3] Bynoe RP. Maxillofacial injuries and life-threatening hemorrhage: Treatment with transcatheter arterial embolization 2003 Jul; 55(1):74-9
[4] Abdullah WA, Al-Mutairi K, Al-Ali Y, Al-Soghier A, Al-Shnwani A Patterns and etiology of maxillofacial fractures in Riyadh City, Saudi Arabia. Saudi Dent J. 2013; 25(1):33-8.

[5] Andreas ZJ, Benoit S, Olivier L, Nikola S, Hanna T, Tateyuki I. Incidence, Etiology and pattern of mandibular fractures in central Switzerland. Swiss Med Wkly. 2011; 141:132-7.

[6] Garg V, Singh H, Vij K. Trends of maxillofacial trauma at tertiary care hospital in rural area of southern Punjab. J Indian Acad Forensic Med. 2012; 34(1):971-3.

[7] Guruprasad Y, Hemavathy OR, Giraddi G, Shetty JN. An assessment of etiological spectrum and injury characteristics among maxillofacial trauma patients of government dental college and research institute, Bangalore. J Nat Sci Biol Med. 2014; 5(1):47.

[8] Bali RK, Sharma P, Garg A, Dhillon G. A comprehensive study on maxillofacial trauma conducted in Yamunanagar, India. J Inj Violence Res. 2013; 5(2):108-16.

[9] Ayana B, Ahmed E. Interpersonal violence related injury at St Luke hospital Oromia Region, Ethiopia. East Cent Afr J Surg. 2012; 17(1):37-42.

[10] Owino RO, Macigo FG, Onyango FJ. Pattern and aetiology of mandibular fractures at Kenyatta national hospital. Afr J Oral Health Sci. 2003; 4(1):17880.

[11] Rubiev M. A retrospective analysis of facial fracture etiologies. J IMAB Annu Proc Sci Pap. 2012; 18(2):153-4.

[12] Chandrashekhar chattopadhyay. Reconstruction of Acquired Frontal Bone Defects Using Titanium Mesh Implants: A Retrospective Study. J. Maxillofac. Oral Surg (Jan-Mar2019)18(1)34-39.

[13] Fonsceca RJ. Mandibular fractures. Oral and maxillofacial trauma. USA: Elsevier Sanders; 2005

[14] Telfer MR, Jones GM, Shepherd JP. Trends in the aetiology of maxillofacial fractures in the United Kingdom (1977-1987). Br J Oral Maxillofac Surg. 1991;29(4):250-5.

[15] Arabion HR, Tabrizi R, Aliabadi E, Gholami M, Zarei K. A retrospective analysis of maxillofacial trauma in Shiraz, Iran: a 6-year-study of 768 patients (2004-2010). J Dent. 2014;15(1):15.

[16] Khadka R, Chaurasia NK. Four years prospective study of the maxillofacial trauma at a tertiary center in western Nepal. J Orofac Sci. 2014;6(2):78.

[17] Abdullah WA, Al-Mutairi K, Al-Ali Y, Al-Soghier A, Al-Shnwani A Patterns and etiology of maxillofacial fractures in Riyadh City, Saudi Arabia. Saudi Dent J. 2013;25(1):33-8.

[18] Wood EB, Freer TJ. Incidence and aetiology of facial injuries resulting from motor vehicle accidents in queensland for a three-year period. Aust Dent J. 2001;46(4):284-8.

[19] Andreas ZJ, Benoit S, Olivier L, Nikola S, Hanna T, Tateyuki I. Incidence, aetiology and pattern of mandibular fractures in central Switzerland. Swiss Med Wkly. 2011; 141:132-7.

[20] Khan AA. A retrospective study of injuries to the maxillofacial skeleton in Harare, Zimbabwe. Br J Oral Maxillofac Surg. 1988;26(5):435-9.

[21] Batista AM, de Ferreira F, Marques LS, Ramos-Jorge ML, Ferreira MC. Risk factors associated with facial fractures. Braz Oral Res. 2012; 26(2):119-25.

[22] Nordberg E. Injuries as a public health problem in sub-Saharan Africa: epidemiology and prospects for control. East Afr Med J. 2000; 77(12 Suppl): S1-43.

[23] Deliverska E. The role of alcohol involvement in maxillofacial trauma. J IMAB Annu Proc Sci Pap. 2012; 18(2):147-9.

[24] Saddki N, Suhaimi AA, Daud R. Maxillofacial injuries associated with intimate partner violence in women. BMC Public Health. 2010; 10(1):268.

\section{AUTHORS}

First Author - Dr Dinesh Pilania, MDS, Oral \& Maxillofacial Surgery, Senior Resident, Dept of Dentistry, Dr S N Medical College, Jodhpur, Rajasthan.

Second Author - Dr Vikas Dev, MDS, Periodontology, Professor \& Head, Dept of Dentistry, Dr S N Medical College, Jodhpur, Rajasthan. 
Third Author - Dr Chandrashekhar Chattopadhyay, MDS, Oral \& Maxillofacial Surgery, Associate Professor, Dept of Dentistry, Dr S N Medical College, Jodhpur, Rajasthan

Correspondence Author - Dr Dinesh Pilania, Senior Resident, Dept of Dentistry, Mathura Das Mathur Hospital, Dr S N
Medical College, @ 9982204101,8905282101,

Dineshpilania17@gmail.com, Plot no 13, Section 7 Extension, New Power House Road, Shastri Nagar, Jodhpur, Rajasthan. 342001 